\title{
A case study of formation and maintenance of a lower stratospheric cirrus cloud over the tropics
}

\author{
M. Sandhya ${ }^{1,2}$, S. Sridharan ${ }^{1}$, M. Indira Devi ${ }^{2}$, K. Niranjan ${ }^{2}$, and A. Jayaraman ${ }^{1}$ \\ ${ }^{1}$ National Atmospheric Research Laboratory, Gadanki 517 112, Pakala Mandal, Chittoor District, \\ Andhra Pradesh, India \\ ${ }^{2}$ Department of Physics, Andhra University, Visakhapatnam, Andhra Pradesh 530003 India \\ Correspondence to: S. Sridharan (susridharan@ narl.gov.in)
}

Received: 28 January 2015 - Revised: 23 April 2015 - Accepted: 2 May 2015 - Published: 29 May 2015

\begin{abstract}
A rare occurrence of stratospheric cirrus at $18.6 \mathrm{~km}$ height persisting for about 5 days during 37 March 2014 is inferred from the ground-based Mie lidar observations over Gadanki $\left(13.5^{\circ} \mathrm{N}, 79.2^{\circ} \mathrm{E}\right)$ and spaceborne observations. Due to the vertical transport by large updrafts on 3 March in the troposphere, triggered by a potential vorticity intrusion, the water vapour mixing ratio shows an increase around the height of $18.6 \mathrm{~km}$. Relative humidity with respect to ice is $\sim 150 \%$, indicating that the cirrus cloud may be formed though homogeneous nucleation of sulfuric acid. The cirrus cloud persists due to the cold anomaly associated with the presence of a 4-day wave.
\end{abstract}

Keywords. Atmospheric composition and structure (cloud physics and chemistry; middle atmosphere - composition and chemistry; volcanic effects)

\section{Introduction}

Cirrus clouds are ubiquitous over the tropics and they significantly influence the radiation budget by reflecting incoming sunlight and regulating outgoing heat radiation from Earth's surface (Liou, 1986; Boehm et al., 1999; Ramanathan and Collins, 1991; Prabhakara et al., 1993). They play a role in the dehydration in the tropical tropopause layer and hence on stratospheric humidity (Gettleman et al., 2002; Jensen et al., 1996a, 2001). In addition, they play a crucial role in regulating global climate sensitivity (Lohmann and Roeckner, 1995). They are frequently observed at higher altitudes $(10-18 \mathrm{~km})$ in the tropics by spaceborne (Wang et al., 1996; Rossow and Schiffer, 1991) and ground-based lidar (Winker and Trepte, 1998; Sunilkumar and Parameswaran, 2005) and targeted aircraft measurements (Jensen et al., 1996b, Spinhirne and Hart, 1990; Heymsfield et al., 1998).

Optically thin cirrus clouds, which are classified based on an optical depth of less than 0.02 are either formed due to an outflow from deep convection or formed in situ (Pfister et al., 2001). The in situ formation of cirrus clouds is identified from the observations of these clouds far from deep convection. However, also in this case, the source of humidity is believed to be a deep convective outflow that has been transported by the upper tropospheric winds (Boehm and Verlinde, 2000). Tropical cirrus clouds can persist for several hours to several days before they dissipate due mainly to sedimentation of ice from the cloud layer or evaporation of ice due to radiative warming of the layer. Based on the cirrus simulations, Boehm et al. (1999) concluded that the mechanism of radiative destabilization and associated cloud circulations could not explain the maintenance of cirrus clouds over the tropics. They suggested that large-scale upward motion either due to Hadley circulation, local convection, or tropical waves is required to maintain the cloud by cooling the cirrus layer adiabatically to reduce the ice loss due to radiative heating. Cirrus clouds mostly appear below the cold point tropopause with their tops coinciding with the cold point height and extending downward (Sunilkumar and Parameswaran, 2005). Some studies from mid-latitudes reported cirrus above the tropopause (Sassen, 1991; Murphy et al., 1990; Wang et al., 1996). Keckhut et al. (2005) noted thin cirrus in the mid-latitude stratosphere $3 \mathrm{~km}$ above the local tropopause. They attributed it to the transport of moist air from the troposphere to the stratosphere through Brewer-Dobson circulation or through local vertical circulation. However, to our knowledge, there are only a few reports 
on the presence of cirrus cloud tops above the tropopause over tropics (Pan and Munchak, 2011; Winker and Trepte, 1998). A case study is presented here, in which the cirrus is identified just above the tropopause height in the groundbased lidar and spaceborne observations. Its formation and maintenance are discussed in this paper.

\section{Data sets used}

\subsection{Mie lidar and radiosonde observations over Gadanki}

The Mie lidar system at Gadanki $\left(13.5^{\circ} \mathrm{N}, 79.2^{\circ} \mathrm{E}\right)$ uses a Nd:YAG pulsed laser source at the second harmonic of $532 \mathrm{~nm}$ operating currently with an energy of $600 \mathrm{~mJ}$ per pulse and a pulse repetition frequency of $50 \mathrm{~Hz}$ as a transmitter and a $35 \mathrm{~cm}$ diameter telescope of Schmidt-Cassegrain type with the field of view of $1 \mathrm{mrad}$ as a receiver (Sivakumar et al., 2003). The received signal is split into co- (P channel) and cross-polarized (S channel) components with nearly equal gains by a polarization beam splitter, and a photo multiplier tube with a narrowband interference filter centred at $532 \mathrm{~nm}$ with full width half maximum of $1.13 \mathrm{~nm}$ is used to count the number of photons with the dwell time of $2 \mu \mathrm{s}$ corresponding to an altitude resolution of $300 \mathrm{~m}$. From the reference altitude $z_{\mathrm{m}}(35 \mathrm{~km})$, where the backscattering contribution is mainly due to air molecules and the aerosol scattering can be neglected, the total backscattering coefficient $\beta_{z}$ is obtained using the inversion algorithm proposed by Klett (1985). The calculated total backscattering coefficient $\beta_{z}$ is further used to calculate the scattering ratio (SR), which is $\beta_{z}(z) / \beta_{\mathrm{m}}(z)$, where $\beta_{\mathrm{m}}(z)$ is the backscattering coefficient at the reference altitude. The SR is unity for an aerosol-free Rayleigh atmosphere and it increases with increasing aerosol concentration. The SR greater than 1.25 can be taken as a threshold for identifying cirrus days (Ramachandran and Jayaraman, 2003; Kulkarni et al., 2008). Meisei GPS radiosondes have been launched daily at Gadanki around 12:00 GMT (17:30 LT) (Nath et al., 2013). The atmospheric parameters, pressure, temperature, zonal and meridional wind velocities and relative humidity are obtained with a height resolution of $\sim 5 \mathrm{~m}$ (sampled at $1 \mathrm{~s}$ intervals), which however are averaged to $100 \mathrm{~m}$ and used for the present work.

\subsection{NCEP daily global analysis data sets and IR brightness temperature}

The National Centers for Environmental Prediction (NCEP) reanalysis project provides daily global temperature and wind information from the surface to lower stratosphere (Kalnay et al., 1996) and the data sets are available with spatial resolution of $2.5^{\circ} \times 2.5^{\circ}$ (http://www.esrl.noaa.gov/psd/data/gridded/data.ncep.html) beginning with 1 January 1997. The temperature and hor- izontal winds are available for 17 pressure levels between 1000 and $10 \mathrm{hPa}$, while the vertical winds are available only for 12 pressure levels from 1000 to $100 \mathrm{hPa}$. The $4 \mathrm{~km}$ merged $\left(60^{\circ} \mathrm{N}-60^{\circ} \mathrm{S}\right)$ infrared (IR) brightness temperature data, from all available geostationary satellites - GOES8/10, METEOSAT-7/5 and GMS - were obtained from the website http://mirador.gsfc.nasa.gov/cgi-bin/mirador/ presentNavigation.pl?tree=project\&project=TRMM for the present study.

\subsection{MODIS cirrus reflectance}

Moderate Resolution Imaging Spectroradiometer (MODIS) has a swath width of $2.330 \mathrm{~km}$ and it images Earth in $36 \mathrm{spec}-$ tral bands (from 0.405 to $14.385 \mu \mathrm{m}$ ). The level-3 MODIS atmosphere daily global product contains roughly 600 statistical data sets that are derived from approximately 80 scientific parameters from four level-2 MODIS atmosphere products, namely, aerosol, water vapour, cloud, and atmosphere profile. The daily gridded cirrus reflectance used in the present study is obtained from the MODIS Terra platform (http:// modis-atmos.gsfc.nasa.gov/MOD08_D3/index.html). There is large disparity between spatially averaged satellite observation and in situ aircraft observation in the horizontal and vertical dimensions. However, the ground-based measurements provide an intermediate scale between aircraft and satellite observations. Mace et al. (2004) concluded that the regionally averaged cloud property derived from MODIS is comparable with that obtained from ground-based instruments. However, the optically thin cirrus pixels were observed to bias slightly towards optically thicker pixels. They also noted that cloud tops of thin cirrus derived using the MODIS algorithm are several hundred metres less than those obtained using ground measurements. However, the MODIS retrieval algorithms give reasonably accurate cirrus properties.

\subsection{CALIPSO cloud signature}

The Cloud-Aerosol Lidar and Infrared Pathfinder Satellite Observations (CALIPSO) measure the vertical distribution of aerosols and clouds, as well as their optical and physical properties, from a near-nadir-viewing geometry, with a two-wavelength (532 and $1064 \mathrm{~nm}$ ) polarization-sensitive lidar. The CALIPSO Vertical Feature Mask (VFM) product (Vaughan et al., 2004) is a level-2 product and it classifies aerosols and clouds, which are separated further into different subclasses based on their physical feature differences (Omar et al., 2003). The VFM is taken from the website http://www.calipso.larc.nasa.gov.

\subsection{Water vapour from the Microwave Limb Sounder Aura}

The Microwave Limb Sounder (MLS) has spatial coverage from $82^{\circ} \mathrm{S}$ to $82^{\circ} \mathrm{N}$, with each profile spaced $1.5^{\circ}$ or 
$\sim 165 \mathrm{~km}$ along the orbit track (13 orbits per day). It scans vertically the Earth's limb (edge) from the stratosphere to the upper troposphere, in $25 \mathrm{~s}$, in five spectral regions centred at $118,190,240,640 \mathrm{GHz}$ and $2.5 \mathrm{THz}$ and measures naturally occurring microwave thermal emissions from the limb of Earth's atmosphere to remotely sense vertical profiles of the atmospheric gases, temperature, pressure and cloud ice. The water vapour mixing ratio is derived from radiances measured primarily by the $190 \mathrm{GHz}$ radiometer. The water vapour mixing ratios and relative humidity with respect to ice (RH_ice) used in the present study are taken from the website http://mirador.gsfc.nasa.gov/ (Waugh, 2005). The recommended useful vertical range for scientific application is between 316 and $0.00215 \mathrm{hPa}$ and the vertical resolution is about $1.5 \mathrm{~km}$ at $316 \mathrm{hPa}$ increasing to $3.5 \mathrm{~km}$ at $4.64 \mathrm{hPa}$, and it degrades to $15 \mathrm{~km}$ above $0.1 \mathrm{hPa}$.

\subsection{AURA/OMI stratosphere Sulfur dioxide}

The Ozone Monitoring Instrument (OMI) provides almost daily global coverage and monitors stratosphere and troposphere layer (STL) ozone, clouds, aerosols and smoke from biomass burning, $\mathrm{SO}_{2}$ from volcanic eruptions, tropospheric pollutants $\left(\mathrm{HCHO}, \mathrm{NO}_{2}\right)$ and ozone depleting gases such as $\mathrm{OClO}$ and $\mathrm{BrO}$ covering the range between 15 and $20 \mathrm{~km}$. The sulfur dioxide product " $\mathrm{OMSO}_{2}$ " contains three values of the $\mathrm{SO}_{2}$ vertical column corresponding to three a priori vertical profiles used in the retrieval algorithm. In the present study, the UTLS (upper troposphere/lower stratosphere) region $\mathrm{OMSO}_{2}$ image is used and was downloaded from the website http://so2.gsfc.nasa.gov.

\subsection{COSMIC RO temperature data}

Constellation Observing System for Meteorology, Ionosphere and Climate (COSMIC), the satellite constellation launched in April 2006 is an active limb sounding technique. COSMIC provides $\sim 1500$ atmospheric profiles (bending angle, refractivity, density, pressure, temperature and humidity) per day, when the GPS signals are tracked by low Earth orbit (LEO) satellite. The basic principle of radio occultation (RO) is the phase delay of GPS signal due to the refractivity of Earth's atmosphere. Gobiet et al. (2007) provide a detailed description of COSMIC RO data retrieval. The refractivity is directly proportional to dry air density, where the moisture is negligible in atmosphere (i.e. above $14 \mathrm{~km}$ in tropics; Foelsche et al., 2008). Assume that the atmosphere is in hydrostatic equilibrium and the application of ideal gas equation provides atmospheric pressure and temperature (Pirscher et al., 2010). For the present study we have taken the dry air retrieval temperature profile within the grid $6-18^{\circ} \mathrm{N}, 70-$ $85^{\circ} \mathrm{E}$. Table 1 lists the sources of data used in the manuscript, parameters and their temporal coverage.

\section{Results}

\subsection{Scattering ratio and thermal structure over Gadanki}

Figure 1a shows the height -time cross section of the scattering ratio (SR) derived from the Mie lidar observations over Gadanki from 1 January to 16 March 2014. The vertical white lines represent data gaps. In the present study, a threshold value of SR > 1.5 is used for the identification of cirrus clouds. Presence of cirrus can be noted in the height region $10-17 \mathrm{~km}$ on many days during January and February. During March, there are not many observations. Within these limited observations, it is found that on 5 and 7 March, larger SRs of 1.72 and 1.63 are observed at heights of 18.6 and $18.9 \mathrm{~km}$, respectively (Fig. 1b). Also on 14 and 15 March (Fig. 1c), large SRs of 1.2 and 1.16 are observed at slightly higher heights of 19.5 and $19.2 \mathrm{~km}$, respectively. However, the SR values are slightly below the threshold for identifying the presence of cirrus, indicating presence of a stratospheric aerosol layer with an LDR (linear depolarization ratio of around 0.015. To infer the ambient temperature at height, where the cirrus is formed, the thermal structure is examined using radiosonde temperature measurements over Gadanki. As the cold point tropopause heights obtained from the radiosonde temperature observations are found to be $16.8,17.1,16.6 \mathrm{~km}$ on the days 5-7 March 2014, respectively, with temperatures around $190 \mathrm{~K}$ (Fig. 1d), the cirrus clouds appear just above the tropopause in the lower stratosphere. The occurrence of cirrus near tropopause is related to the cold anomalies induced by the equatorial Kelvin waves (Boehm and Verlinde, 2000). In the present case also, the time-height cross section of time-mean removed temperature shows the presence of warm anomalies progressing downward beginning from 28 February and again from 8 March in the height region of $17-19 \mathrm{~km}$, indicating the presence of a wave having 4-day periodicity. Associated with the wave, cold anomalies are present on 4-7 March in between the two warm anomalies (data gap on 5 March) at a height where the cirrus cloud was observed, as earlier noted by Boehm and Verlinde (2000). The spatial and temporal extents of the rare stratospheric cirrus are investigated using spaceborne MODIS and CALIOP (Cloud-Aerosol Lidar with Orthogonal Polarization) observations.

\subsection{Cirrus observations by MODIS and CALIOP}

Figure 2a shows the cirrus reflectance on 3 March over the region $10-17^{\circ} \mathrm{N}$ and $66-84^{\circ} \mathrm{E}$. It can be inferred from the figure that the cirrus reflectance shows larger values over 12.5$16.5^{\circ} \mathrm{N}$ and $76.5-81.5^{\circ} \mathrm{E}$ with a maximum value of 0.06 at $15.5^{\circ} \mathrm{N}$ and $79.5^{\circ} \mathrm{E}$, which confirms the presence of cirrus clouds around Gadanki on 3 March itself.

As MODIS does not give height information, the vertical feature mask, obtained from the CALIOP lidar onboard 
Table 1. Data sets used, parameters and their temporal coverage shown.

\begin{tabular}{lll}
\hline Data Source & Parameter & Temporal coverage shown \\
\hline Gadanki Mie lidar & Scattering ratio & 1 January-16 March 2014 \\
Gadanki radiosonde & Temperature & 24 February-11 March 2014 \\
MODIS & Cirrus reflectance & 3 March 2014 \\
CALIPSO & Vertical feature mask & 3 March 2014 \\
MLS & Relative humidity & 3 March 2014 \\
NCEP & IR brightness temperature & 3 March 2014 \\
COSMIC RO & Potential vorticity & 28 February-6 March 2014 \\
OMI & Temperature & 24 February-11 March 2014 \\
\hline
\end{tabular}
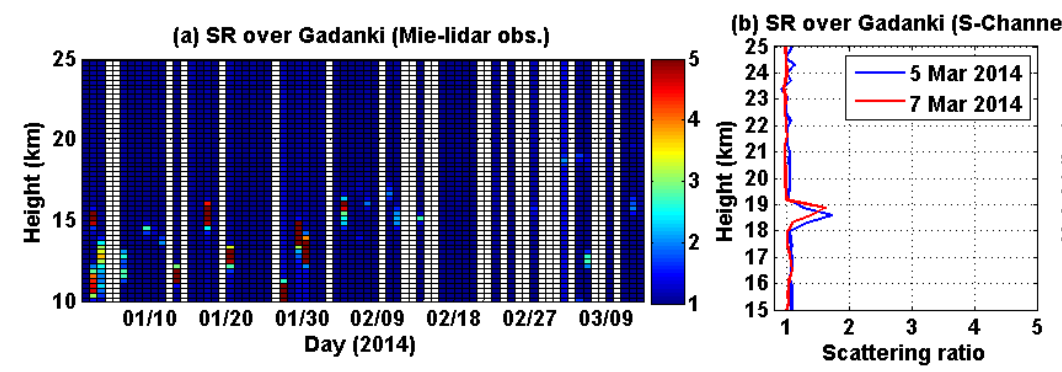

(c) SR over Gadanki
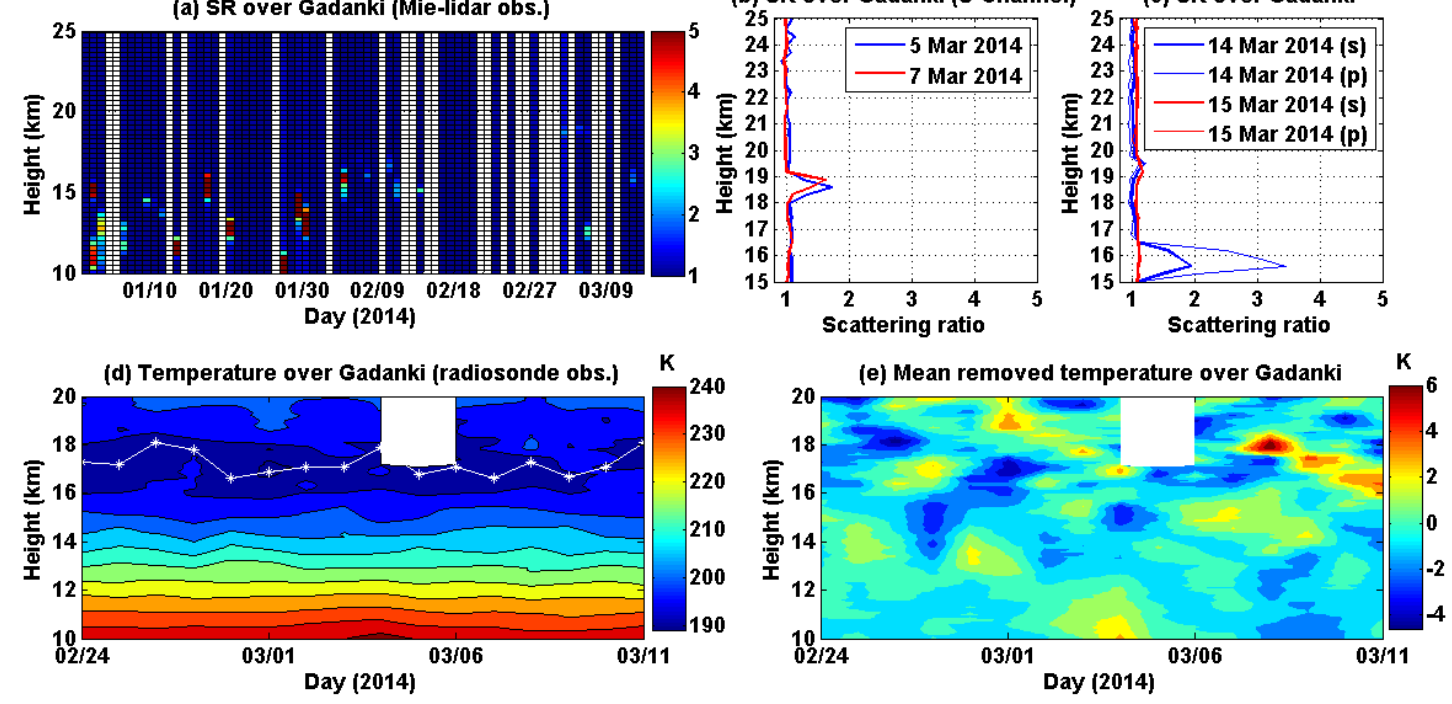

Figure 1. (a) Time-height cross section of scattering ratio from 1 January to 16 March 2014, (b) height variation of scattering ratio on 5 and 7 March 2014 from cross-polarized (S) channel, (c) height variation of scattering ratio for 14-15 March 2014 from the co- (P) and cross-polarized (S) channels obtained from Mie lidar observations over Gadanki and (d, e) height variations of (d) daily temperature and (e) mean removed daily temperature for 24 February-11 March 2014 obtained from radiosonde observations at Gadanki. The daily cold point tropopause variation is plotted with white stars $(*)$ in $(\mathbf{d})$.

the CALIPSO satellite, is used in order to obtain the cirrus occurrence height. It is found that CALIPSO did not pass through the longitude region, where high cirrus reflectance is observed by MODIS. However, it shows a cloud signature along with a stratospheric layer near to $15^{\circ} \mathrm{N}$ and $70.5^{\circ} \mathrm{E}$ at altitudes of $18-19 \mathrm{~km}$ on 3 March (Fig. 2b). It may be noted that cirrus is observed in the same height region in the Mie lidar observations available over Gadanki on 5 and 7 March, indicating that the cirrus could persist for about 5 days. Unfortunately, both MODIS and CALIPSO did not pass through the region close to Gadanki on 5 and 7 March 2014.

As cirrus has normally been observed just below the tropopause height (Sunilkumar and Parameswaran, 2005) and earlier studies showed that cirrus cloud occurrence over Gadanki decreased drastically to less than $5 \%$ above $17 \mathrm{~km}$ (Sivakumar et al., 2003; Parameswaran et al., 2004), the cirrus observed in the present study just above the tropopause could be considered a rare case. In the following, we investigate the causative mechanisms for this cirrus and its persistence for a long duration. Generally, there are two mechanisms suggested for the formation of cirrus clouds. Cirrus can be formed from anvil tops of deep convective clouds and also due to supersaturation of air by a cold temperature anomaly (Pfister et al., 2001).

\subsection{PV intrusion and deep convection}

As the spatial extension of cirrus is large, it is inferred that deep convection must have occurred over a large area, which can be triggered by a potential vorticity (PV) intrusion. Recently, Sandhya and Sridharan (2014) reported a climatology of PV intrusions and they observed that the number of $\mathrm{PV}$ intrusions is higher during spring equinox months over the Indian sector, whereas it is higher during winter over 
(a) Cirrus reflectance on 3 Mar 2014

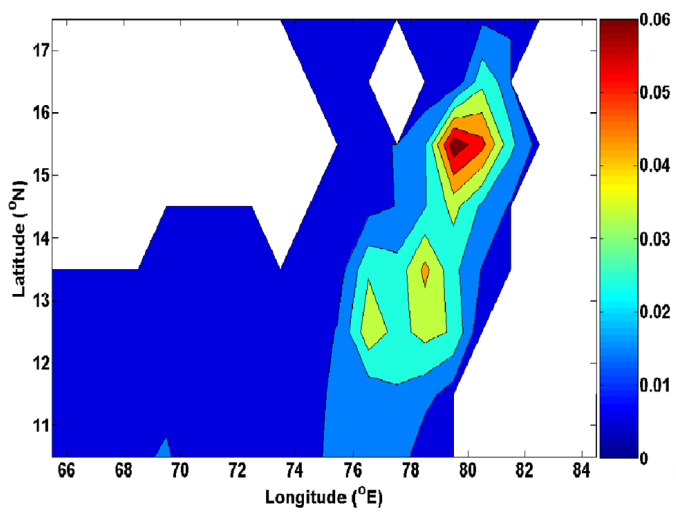

(b) Vertical feature mask on 3 Mar 2014 at 21:05:53.8- 21:19:22.4

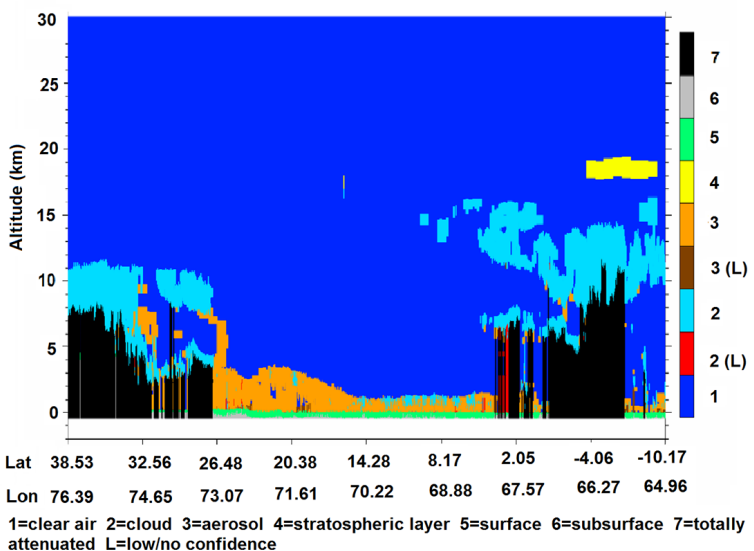

Figure 2. (a) Longitude-latitude cross section of cirrus reflectance on 3 March 2014 from MODIS Terra platform and (b) height variation of the vertical feature mask obtained from CALIPSO on its orbit track from 21:05 to 21:19 UT on 3 March 2014.

the Pacific and Atlantic sectors (Waugh and Polvani, 2000). They also found that the spatial and temporal extents of convection and rainfall closely followed those of PV intrusion. The occurrence of PV intrusions is confirmed in the present case from the longitude-time cross section of $\mathrm{PV}$ at $15^{\circ} \mathrm{N}$ at $250 \mathrm{hPa}$ shown in Fig. 3a. In the figure, a PV intrusion event can be identified on 3 March and it occurs with a maximum $\mathrm{PV}$ value of 1.47 PVU (PV units) over $65-70^{\circ} \mathrm{E}$.

Deep convection nearly always occurs at the downstream side of the PV intrusions (Funatsu and Waugh, 2008; Sandhya and Sridharan, 2014). Figure $3 b$ shows longitudelatitude cross section of brightness temperature on 3 March 2014 (PV intrusion day). The brightness temperature shows a low value $(<240 \mathrm{~K})$ over $15-16.5^{\circ} \mathrm{N}$ and $76-78^{\circ} \mathrm{E}$, as expected from any PV intrusion, which normally triggers convection in the eastward sides of the intrusion region. On other days there is no convection which can be inferred from high brightness temperature (>280 K). Since the cirrus observed at the height of $18-19 \mathrm{~km}$, large updrafts must have occurred to transport the water vapour above the tropopause. From the longitude-pressure cross section of pressure velocity from the surface to $100 \mathrm{hPa}$ at $15^{\circ} \mathrm{N}$ shown in Fig. 3c, we can infer a large updraft from the surface onwards, persisting up to $100 \mathrm{hPa}(\sim 16 \mathrm{~km})$ over $75-80^{\circ} \mathrm{E}$ on $3 \mathrm{March} 2014$. Assuming the large updrafts continue at higher altitudes, we can presume that they could have transported water vapour to above the tropopause.

\subsection{Water vapour above tropopause}

From the daily variation of MLS relative humidity with respect to ice averaged for $10-17^{\circ} \mathrm{N}$ and $60-85^{\circ} \mathrm{E}$ from 1 to 5 March at $82 \mathrm{hPa}(\sim 18.6 \mathrm{~km})$, where the cirrus clouds are observed, it is inferred that a higher mixing ratio of water vapour ( $3.8 \mathrm{ppm}$ ) is observed on $3 \mathrm{March}$, when compared to other days (not shown). This confirms the transport of wa- ter vapour to the region just above tropopause by the large updrafts triggered by the PV anomaly.

Cirrus clouds are composed of ice crystals, as they form at heights where temperature is low. However, ice nucleation does not happen directly from water vapour, it requires a preexisting particle. There are two methods for the formation of ice nucleation: homogeneous nucleation and heterogeneous nucleation (Cziczo et al., 2013). The heterogeneous nucleation is possible even just below $0{ }^{\circ} \mathrm{C}$ and at $\mathrm{RH}$ with respect to ice $\sim 100 \%$ if some materials such as mineral dust and metallic particles are present. However, it involves the surfaces of insoluble particles serving as ice nuclei. For the homogeneous nucleation, a supersaturation with respect to ice is necessary. We investigated the height variation of RH (\%) with respect to ice (RH_ice) from the pressure level of $316-56 \mathrm{hPa}$ over $10-17^{\circ} \mathrm{N}$ and $60-80^{\circ} \mathrm{E}$ on 3 March. The RH_ice profiles are available at 10 latitude-longitude points within $10-17^{\circ} \mathrm{N}$ and $60-80^{\circ} \mathrm{E}$. Among these 10 profiles, it is noted that in 3 profiles - corresponding to the locations $16.32^{\circ} \mathrm{N}, 70.65^{\circ} \mathrm{E} ; 14.48^{\circ} \mathrm{N}, 70.32^{\circ} \mathrm{E}$; and $13.35^{\circ} \mathrm{N}$, $70.00^{\circ} \mathrm{E}-\mathrm{RH}$-ice exceeds $100 \%$ with respective RH values of 123,134 and $146 \%$, as shown Fig. 3d. Since for homogeneous ice nucleation the water vapour should be supersaturated with respect to ice, and the RH_ice is close to $150 \%$, we can infer that the cirrus formation may be due to homogeneous ice nucleation of aqueous solution of water vapour.

\subsection{Kelud eruption and sulfate cloud}

On 13 February 2014 at 15:50 UT, Mount Kelud $\left(\sim 7.9^{\circ}\right.$ N, $\left.112.3^{\circ} \mathrm{E}\right)$ in Indonesia erupted explosively. The eruption injected ash above $16 \mathrm{~km}$ height. The modelled vertical distribution of fine ash shows maximum concentration of $9 \pm 3 \mathrm{mg} \mathrm{m}^{-3}$ in the height region of $16-20 \mathrm{~km}$ near the eruption region (Kristiansen et al., 2015). As the Kelud eruption occurred, it was investigated whether the observed strato- 
(a) NCEP. PV at $15^{\circ} \mathrm{N}(2014)$

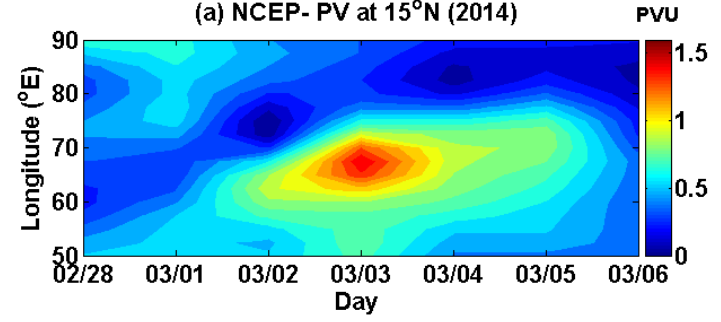

(c) NCEP- Omega (03 March 2014)

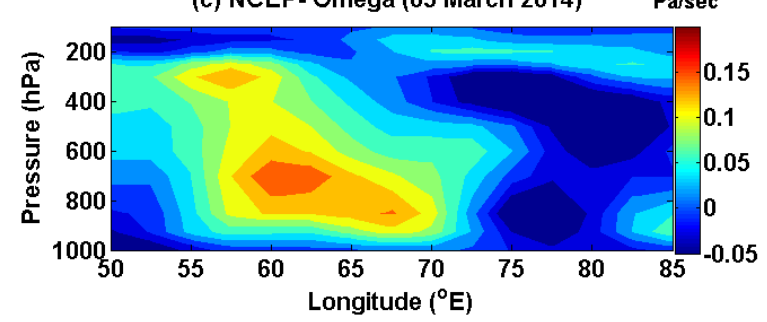

(b) NCEP-IR Brightness temperature (03 March 2014) K

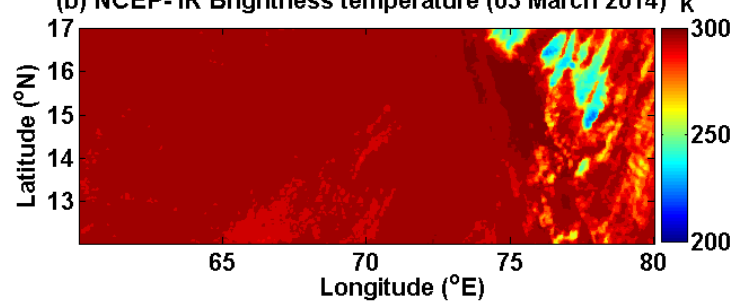

(d) MLS- RH with respect to ice (03 March 2014)

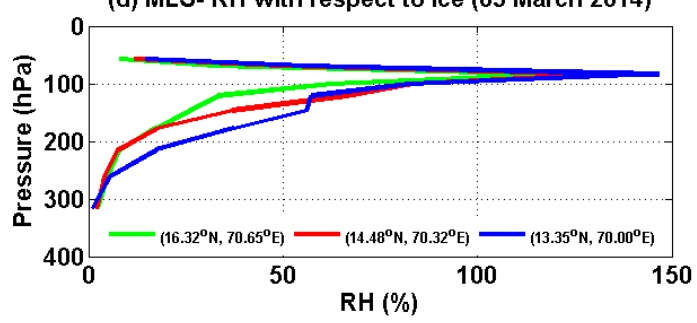

Figure 3. (a) Longitude-time cross section of PV (PVU) at $250 \mathrm{hPa}$ over $15^{\circ} \mathrm{N}$ from 28 February to $6 \mathrm{March} 2014$, (b, c) longitude-latitude cross sections of $(\mathbf{b})$ brightness temperature $(\mathrm{K})$ at $15^{\circ} \mathrm{N}$, (c) omega (vertical pressure velocity) $(\mathrm{Pa} / \mathrm{s})$ at $15^{\circ} \mathrm{N}$ on $3 \mathrm{March} 2014$, (d) height profiles of $\mathrm{RH}$ _ice over the locations $16.32^{\circ} \mathrm{N}, 70.65^{\circ} \mathrm{E} ; 14.48^{\circ} \mathrm{N}, 70.32^{\circ} \mathrm{E}$; and $13.35^{\circ} \mathrm{N}, 70.00^{\circ} \mathrm{E}$ on $3 \mathrm{March} 2014$.

spheric cirrus had any relation with the eruption. It is possible that after a major volcanic eruption, $\mathrm{SO}_{2}$ gas injected into the stratosphere could become photo-oxidized and combine with water vapour and possibly aerosols to form the cirrus cloud (Sassen et al., 1989). In the present study, the OMI sensor observed the STL $(15-20 \mathrm{~km})$ vertical column $\mathrm{SO}_{2}$, largely present over Indonesia on 22 February 2014 and also stretched westward towards the African continent (Fig. 4a). To examine whether there is a transport of air towards India, one of the back trajectory models, namely, the Hybrid Single Particle Lagrangian Integrated Trajectory Model (HYSPLIT) is used (see Draxler and Rolph, 2013 for details) to obtain the back trajectory of the air parcel. The approximate coordinates of Gadanki $\left(13.5^{\circ} \mathrm{N}, 79.5^{\circ} \mathrm{E}\right), 18 \mathrm{~km}, 3$ March 2014, are given as the final geographical position, height level of the air parcel and its destination date, respectively, to examine the origin of the stratospheric cirrus layer observed on 3 April. The $168 \mathrm{~h}$ back trajectory is calculated with a new trajectory created for every $12 \mathrm{~h}$ and the result is shown in Fig $4 \mathrm{~b}$. It can be inferred from the figure that the air parcel comes from around $10^{\circ} \mathrm{N}, 50^{\circ} \mathrm{E}$, and the height of the air parcel remains at around $18 \mathrm{~km}$ throughout the trajectory. This suggests that there is a transport of air from Africa at least on 22 February to India and this could have carried $\mathrm{SO}_{2}$ to India at stratospheric heights.

\subsection{Maintenance of cirrus}

Once formed, the tropical cirrus clouds can persist for several hours to several days. From the combination of CALIPSO, MODIS and Mie lidar observations, we can infer the persistence of the stratospheric cirrus for at least 5 days. The large upward motion and cold temperature anomalies associated with the tropical waves could lead to the persistence of the cirrus clouds (Boehm et al., 1999; Taylor et al., 2011). The data as discussed in Sect. 3.1 show the presence of warm anomalies progressing downward beginning from 28 February and again from 8 March in the height region of 17-19 km, indicating the presence of a wave having 4-day periodicity. Associated with the wave, cold anomalies are present in between the two warm anomalies on 4-7 March (data gap on 5 March) at a height where the cirrus cloud was observed. The cold anomalies could be a reason for the persistence of the cirrus cloud for about 5 days. To confirm the existence of a 4-day wave with its cold anomaly during 4-7 March COSMIC RO temperature data have been used. COSMIC RO provides data with high spatial and temporal resolution in the UTLS region (Pirscher et al., 2010). Figure 5 shows time-height variation of mean removed (Fig. 5a) and 3-5day band-pass filtered (Fig. 5b) COSMIC RO temperature from 24 February to 11 March. The presence of a 4-day wave in the height range of $18-20 \mathrm{~km}$ and the persistence of a warm anomaly from 28 February and a cold anomaly from 4 February, as earlier noted in Gadanki radiosonde temperature observations (Fig. 1e), can be inferred from the figure.

\section{Discussion and conclusions}

The Mie lidar observations over Gadanki $\left(13.5^{\circ} \mathrm{N}, 79.2^{\circ} \mathrm{E}\right)$ show the presence of cirrus cloud in the lower stratosphere just above the tropopause around $18.6 \mathrm{~km}$ on 5 and 7 March 2014. Kulkarni et al. (2008) studied the frequency of occurrence of cirrus over Gadanki using Mie lidar observations for the years 2001-2005 and they found that $22 \%$ of cirrus top occurs in the $16-17 \mathrm{~km}$ height region, $15 \%$ of cirrus top occurs at $10-12 \mathrm{~km}$, and only less than $5 \%$ of cirrus top 
(a) AURA/OMI- 22 Feb 2014, 4:01- 14:01 UTC

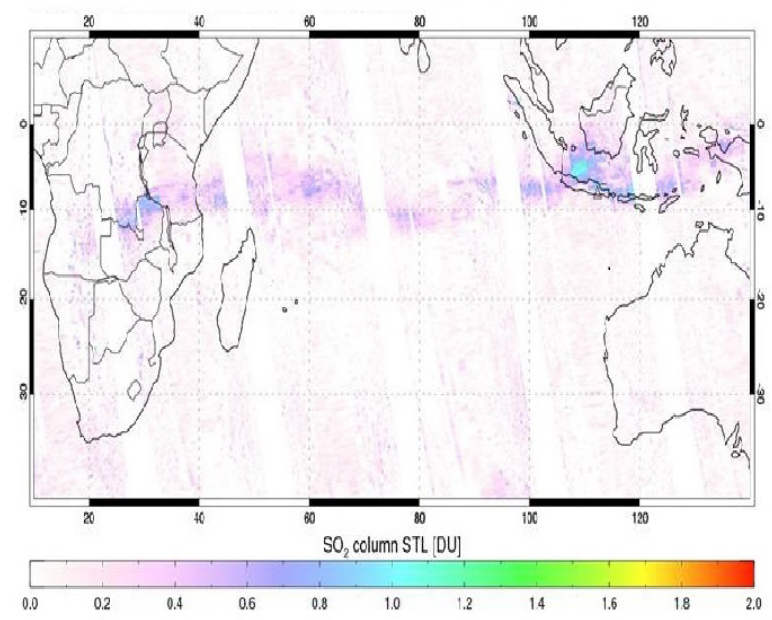

(b) NOAA HYSPLIT MODEL- Backward trajectories ending at 6:00 UTC on 3 Mar 2014

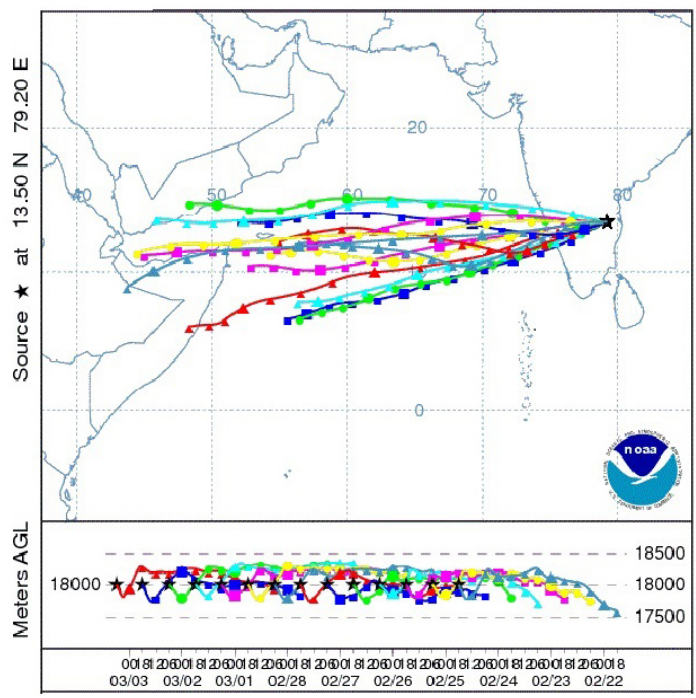

Figure 4. (a) Latitude-longitude image of OMI Aura stratosphere and troposphere layer vertical column $\mathrm{SO}_{2}$ for the height region of $15-$ $20 \mathrm{~km}$ on 22 February 2014 and (b) $168 \mathrm{~h}$ back trajectory ending at 06:00 UT on 3 March 2014 using the National Oceanic Atmospheric Administration (NOAA) HYSPLIT model.

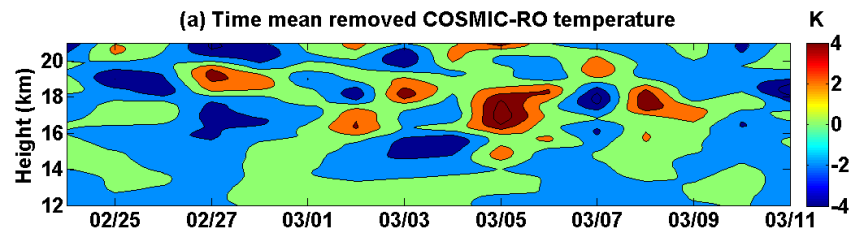

(b) 3-5 day bandpass filtered CoSMIC-RO temperature

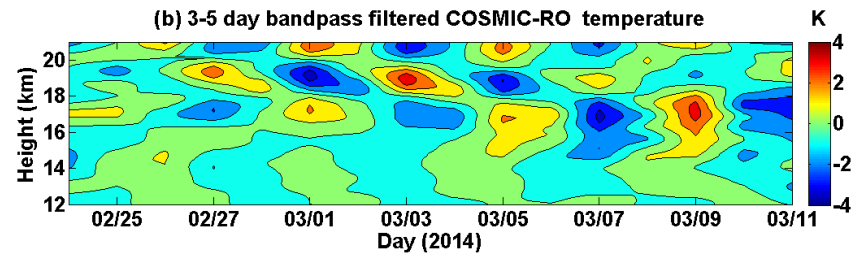

Figure 5. (a) Mean removed daily COSMIC RO temperature and (b) 3-5 day band-pass filtered daily COSMIC RO temperature for the period 24 February-11 March 2014.

occurs above $17 \mathrm{~km}$. Sunilkumar and Parameswaran (2005) observed cirrus clouds mostly in the altitude region of 13$16 \mathrm{~km}$ with the top always below the cold point tropopause. In the present study, a cirrus cloud was observed in the lower stratosphere $(18.6 \mathrm{~km})$ just above the tropopause. From the combination of the ground-based Mie lidar and spaceborne observations, we can infer that the cirrus begins to form on 3 March and it persists for at least 5 days.

The cirrus clouds are formed in the tropopause layer either as an outflow from deep cumulonimbus convection or in situ formation (Pfister et al., 2001). General circulation model results suggest that the climate sensitivity in the cirrus included model atmosphere is $20 \%$ higher than in a clear-sky refer- ence atmosphere because the increase of cirrus emissivity in the warmer atmosphere contributes substantially to the overall positive cloud feedback (Lohmann and Roeckner, 1995). The existence of deep convection is inferred from low brightness temperature. Besides, the NCEP vertical winds show updrafts prevailing throughout the tropospheric column in that location on this day, indicating the presence of deep convection. As a result of the updrafts and deep convection induced by the PV intrusion, the MLS water vapour mixing ratio shows an increase on 3 March around $18.6 \mathrm{~km}$.

For the ice nucleation to take place, water vapour alone is normally not sufficient, it requires a preexisting particle (Pruppacher and Klett, 1997). A few RH_ice profiles within $10-17^{\circ} \mathrm{N}$ and $60-80^{\circ} \mathrm{E}$ show $\mathrm{RH}$ values close to $150 \%$ indicating that the cirrus must be formed due to homogeneous nucleation, which requires that the relative humidity must be strongly supersaturated with respect to ice and the temperature below $235 \mathrm{~K}$ (Lynch et al., 2002). It is likely that the water vapour was injected above tropopause due to strong updrafts reacting with background $\mathrm{SO}_{2}$ to form sulfuric acid droplets, which homogenously nucleate to form the cirrus above the tropopause. It is also probable that the air with large $\mathrm{SO}_{2}$ content might have been transported to the Indian sector due to the Kelud eruption, which occurred on 13 February 2014. The eruption ejected ash cloud covering an area of about $500 \mathrm{~km}$ in diameter, with the total ejected material estimated at $1.2 \times 10^{8}$ to $1.6 \times 10^{8} \mathrm{~m}^{-3}$. The presence of the ash cloud can be observed at nearly $20 \mathrm{~km}$ altitude with sections of the plume reaching to nearly $30 \mathrm{~km}$ (See http://eosweb.larc.nasa.gov/ project/calipso/images/MountKeludEruption.png). It is pos- 
sible that after a major volcanic eruption, $\mathrm{SO}_{2}$ gas injected into the stratosphere could become photo-oxidized and combine with water vapour and possibly aerosols to form the cirrus cloud (Sassen et al., 1989). In the present study, from the OMI $\mathrm{SO}_{2}$ in UTLS region, it is inferred that this ash gets transported to the west of the Indian sector for the first few days after the eruption and further advected to the east, crossing India, which is confirmed by using trajectory analysis. However, the total number concentration of background aerosol in the tropical tropospheric layer is in the order of $\sim 50-80 \mathrm{~cm}^{-3}$ (Spichtinger and Kraemer, 2013) and it may be high enough to allow for homogeneous ice formation, even if the air with high $\mathrm{SO}_{2}$ content did not reach the Indian sector.

Later, after the decay of the cirrus cloud, the presence of a stratospheric aerosol layer at $\sim 19 \mathrm{~km}$ is also inferred from the height profiles of SR and LDR obtained from Mie lidar observations over Gadanki on 14-15 March. If it is a sulfate aerosol layer, the LDR must be greater than 0.1. However, the low depolarization value of 0.015 suggests that the presence of other chemical species such as ammonium sulfate droplets formed due to the reaction of naturally occurring ammonia with sulfuric acid (Sassen et al., 1989), instead of ammonium sulfate crystals, in which case the depolarization value is normally around 0.04. Bigg (1986) suggested that the tropospheric-stratospheric exchange process could introduce ammonia into the stratosphere.

Once formed, the tropical cirrus clouds can normally persist for several hours to several days. In the present study, the cirrus cloud persisted at least 5 days. Large upward motions and cold temperature anomalies induced by equatorial waves would be required for the persistence of cirrus clouds (Boehm et al., 1999). The equatorial waves are observed in the upper troposphere and lower stratosphere region with a wide range of wavelengths and wave periods (Zhang and Geller, 1994). The Gadanki radiosonde and COSMIC RO temperature anomaly shows alternate warm and cold anomalies propagating downward during 28 February- 8 March in the height region of $17-19 \mathrm{~km}$, indicating the presence of a wave having a 4-day periodicity. The presence of cold anomalies on 4-7 March at a height where cirrus is observed is suggested as a reason for the maintenance of the cirrus cloud for about 5 days.

Acknowledgements. The CALIPSO image used in this paper has been downloaded from the website http://www-calipso.larc.nasa. gov/products/lidar/browse_images/production/. NCEP Reanalysis data provided by the NOAA/OAR/ESRL PSD, Boulder, Colorado, USA, from their web site at http://www.esrl.noaa.gov/psd/ in any documents or publications using these data.

The topical editor V. Kotroni thanks the one anonymous referee for help in evaluating this paper.

\section{References}

Bigg, E. K.: Ammonium compounds in stratospheric aerosols, Tellus, 38B, 62-66, 1986.

Boehm, M. T. and Verlinde, J.: stratospheric influence on upper tropospheric tropical cirrus, Geophys. Res. Lett., 27, 3209-3212, doi:10.1029/2000GL011678, 2000.

Boehm, M. T., Verlinde, J., and Ackerman, T. P.: On the maintenance of high tropical cirrus, J. Geophy. Res., 104, 24423-24433, 1986.

Boehm, M. T., Verlinde, J., and Ackerman, T. P.: On the maintenance of high tropical cirrus, J. Geophys. Res., 104, 2442324433, 1999.

Cziczo, D. J., Froyd, K. D., Hoose, C., Jensen, E. J., Diao, M., Zondlo, M. A., Smith, J. B., Twohy, C. H., and Murphy, D. M.: Clarifying the dominant sources and mechanisms of cirrus cloud formation, Science, 340, 6138, doi:10.1126/science.1234145, 2013.

Draxler, R. R. and Rolph, G. D.: HYSPLIT (HYbrid Single-Particle Lagrangian Integrated Trajectory) Model access via NOAA ARL READY Website, available at: http://www.arl.noaa.gov/ HYSPLIT.php, NOAA Air Resources Laboratory, College Park, MD, 2013.

Foelsche, U., Borsche, A., Steiner, K., Gobiet, A., Pirscher, B., Kirchengast, G., Wickert, J., and Schmidt, T.: Observing upper troposphere-lower stratosphere climate with radio occultation data from the CHAMP satellite, Clim.Dyn., 31, 49-65, doi:10.1007/s00382-007-0337-7, 2008.

Funatsu, B. M. and Waugh D. W.: Connections between potential vorticity intrusions and convection in the eastern tropical $\mathrm{Pa}$ cific, J. Atmos. Sci., 65, 987-1002, doi:10.1175/2007JAS2248.1, 2008.

Gettelman, A., Randel, W. J., Wu, F., and Massie, S. T.: Transport of water vapour in the tropical tropopause layer, Geophys. Res. Lett., 29, 1009, doi:10.1029/2001GL013818, 2002.

Gobiet, A., Kirchengast, G., Manney, G. L., Borsche, M., Retscher, C., and Stiller, G.: Retrieval of temperature profiles from CHAMP for climate monitoring: intercomparison with Envisat MIPAS and GOMOS and different atmospheric analyses, Atmos. Chem. Phys., 7, 3519-3536, doi:10.5194/acp-7-3519-2007, 2007.

Heymsfield, A. J., McFarquhar, G. M., Collins, W. D., Goldstein, J. A., Valero, F. P. J., Spinhirne, J., Hart, W., and Pilewskie, P.: Cloud properties leading to highly reflective tropical cirrus: Interpretations from CEPEX, TOGA COARE, and Kwajalein, Marshall Islands, J. Geophys. Res., 103, 8805-8812, 1998.

Jensen, E. J., Toon, O. B., Pfister, L., and Selkirk, H. B.: Dehydration of the upper troposphere and lower stratosphere by subvisible cirrus clouds near the tropical tropopause, Geophys. Res. Lett., 23, 825-828, 1996a.

Jensen, E. J., Toon, O. B., Selkirk, H. B, Spinhirne, J. D., and Schoeberl, M. R.: On the formation and persistence of subvisible cirrus clouds near the tropical tropopause, J. Geophys. Res., 101, 21361-21375, 1996b.

Jensen, E. J., Pfister, L., Ackerman, A. S., and Tabazadeh, A.: A conceptual model of the dehydration of air due to freeze-drying by optically tin laminar cirrus rising slowly across the tropical tropopause, J. Geophys. Res., 106, 17273-17252, 2001.

Kalnay, E., Kanamitsu, M., Kistler, R., Collins, W. , Deaven, D., Gandin, L., Iredell, M., Saha, S., White, G., Woollen, J., Zhu, Y., 
Leetmaa, A., Reynolds, R., Chelliah, M., Ebisuzaki, W., Higgins, W., Janowiak, J., Mo, K. C., Ropelewski, C., Wang, J., Jenne, R., and Joseph,D.: The NCEP/NCAR 40-Year Reanalysis Project, Bull. Amer. Meteor. Soc., 77, 437-471, 1996.

Keckhut, P., Hauchecorne, A., Bekki, S., Colette, A., David, C., and Jumelet, J.: Indications of thin cirrus clouds in the stratosphere at mid-latitudes, Atmos. Chem. Phys., 5, 3407-3414, doi:10.5194/acp-5-3407-2005, 2005.

Klett, J. D.: Lidar inversion with variable backscatter/extinction ratios. App. Optics, 24, 1638-1643, 1985.

Kristiansen, N. I., Prata, A. J., Stohl, A., and Carn, S. A.: Stratospheric volcanic ash emissions from the 13 February 2014 Kelut eruption, Geophys. Res. Lett., 42, 588-596, doi:10.1002/2014GL062307, 2015.

Kulkarni, P., Ramachandran, S., Bhavanikumar, Y., Narayana Rao, D., and Krishnaiah, M.: Features of upper troposphere and lower stratosphere aerosols observed by lidar over Gadanki, a tropical Indian station, J. Geophys. Res., 113, D17207, doi:10.1029/2007JD009411, 2008.

Liou, K.-N.: Influence of cirrus clouds on weather and climate processes: A global perspective, Mon. Weather Rev., 114, 11671199, 1986.

Lohmann, U. and Roeckner, E.: Influence of cirrus cloud radiative forcing on climate and climate sensitivity in general circulation model, J. Geophys. Res., 100, 16305-16323, 1995.

Lynch, D. K., Sassen, K., Starr, D. O., and Stephens, G.: Cirrus, Oxford University Press, New York, 480 pp., 2002.

Mace, G. G., Zhang, Y., Platnick, S., King, M. D., Minnis, P., and Yang, P.: Evaluation of cirrus cloud properties derived from MODIS data using cloud properties derived from ground based observations collected at the ARM SGP site, J. Appl. Meteor., 44, 221-240, 2005.

Murphy, D. M., Kelly, K. K., Tuck, A. F., Proffitt, M. H., and Kinne, S.: Ice saturation at the tropopause observed from the ER-2 aircraft, Geophys. Res. Lett., 17, 353-356, 1990.

Nath, D., Sridharan, S., Sathishkumar, S., Gurubaran, S., and Chen, W.: Lower stratospheric gravity wave activity over Gadanki $\left(13.5^{\circ} \mathrm{N}, 79.2^{\circ} \mathrm{E}\right)$, J. Atmos. Sol.-Terr. Phys., 94, 54-64, doi:10.1016/j.jastp.2012.12.013, 2013.

Omar, A. H., Winker, D., and Won, J.: Aerosol models for the CALIPSO lidar inversion algorithms, Proceedings of SPIE. Laser Radar Technology for Remote Sensing, 5240, 153-164, 2003.

Pan, L. L. and Munchak, L. A.: Relationship of cloud top to the tropopause and jet structure from CALIPSO data, J. Geophys. Res. 116, D12201, doi:10.1029/2010JD015462, 2011.

Parameswaran, K., Sunilkumar, S. V., Krishna Murthy, B. V., and Satheesan, K.: Lidar observations of high altitude cirrus clouds near the tropical tropopause, Adv. Space Sci., doi:10.1016/j.asr.2003.08.64, 845-850, 2004.

Pfister, L., Selkirk, H. B., Jensen, E. J., Schoeberl, M. R., Toon, O. B., Browell, E. V., Grant, W. B., Gary, B., Mahoney, M. J., Bui, T. V., and Hintsa, E.: Aircraft observations of thin cirrus clouds near the tropical tropopause, J. Geophys. Res., 106, 9765-9786, doi:10.1029/2000JD900648, 2001.

Pirscher, B., Foelsche, U., Borsche, M., Kirchengast, G., and Kuo, Y. H.: Analysis of migrating diuranal tides detected in FORMOSAT-3/COSMIC temperature data, J. Geophys. Res., 115, D14108, doi:10.1029/2009JD013008, 2010.
Prabhakara, C., Kratz, D. P., Yoo, J.-M., Dalu, G., and Vernekar, A.: Optically thin cirrus clouds: Radiative impact on the warm pool, J. Quant. Spectrsoc. Radiat. Transfer, 49, 467-483, 1993.

Pruppacher, H. R. and Klett, J. D.: Microphysics of clouds and precipitation, Kluwer Academic, Dordrecht, Second Edition, 309354, 1997.

Ramachandran, S. and Jayaraman, A.: Balloon-borne study of the upper tropospheric and stratospheric aerosols over a tropical station in India, Tellus, 55b, 820-836, 2003.

Ramanathan, V. and Collins, W.: Thermodynamics regulation of ocean warming by cirrus clouds deduced from observations of the 1987 El-Nino, Nature, 351, 27-32, doi:10.1038/351027a0, 1991.

Rossow, W. B. and Schiffer, R. A.: ISCCP cloud data products, Bull. Am. Meteorol.Soc., 72, 2-20, 1991.

Sassen, K.: Corona-producing cirrus cloud properties derived from polarization lidar and photographic analyses, Appl. Opt., 30, 3421-3552, 1991.

Sassen, K., Zhao, H., and Yu, B.: Backscatter laser depolarization studies of simulated stratospheric aerosols: crystallized sulfuric acid droplets, App. Opt., 28, 3024-3029, 1989.

Sandhya, M. and Sridharan, S.: Observational relations between potential vorticity intrusions and premonsoon rainfall over Indian sector, Atmos. Res., 137, 80-90, 2014.

Sivakumar, V., Bhavanikumar, Y., Rao, P. B., Mizutani, K., Aoki, T., Yasui, M., and Itabe, T.: Lidar observed characteristics of the tropical cirrus clouds, Radio Sci., 38, 1094, doi:10.1029/2002RS002719, 2003.

Spinhirne, J. D. and Hart, W. D.: Cirrus structure and radiative parameters from airborne lidar and spectral radiometer observations: The 28 October 1986 FIRE study, Mon. Weather Rev., 118, 2329-2343, 1990.

Spichtinger, P. and Krämer, M.: Tropical tropopause ice clouds: a dynamic approach to the mystery of low crystal numbers, Atmos. Chem. Phys., 13, 9801-9818, doi:10.5194/acp-13-98012013, 2013.

Sunilkumar, S. V. and Parameswaran, K. Temperature dependence of tropical cirrus properties and radiative effects, J. Geophys. Res., 110, DI3205, doi:10.1029/2004JD005426, 2005.

Taylor, J. R., Randel, W. J., and Jensen, E. J.: Cirrus cloudtemperature interactions in the tropical tropopause layer: a case study, Atmos. Chem. Phys., 11, 10085-10095, doi:10.5194/acp11-10085-2011, 2011.

Vaughan, M., Young, S., Winker, D. M., Powell, K., Omar, A., Liu, Z., Hu, Y., and Hostetler, C.: Fully automated analysis of space-based lidar data: an overview of the CALIPSO retrieval algorithms and data products, Proceedings of SPIE, Laser Radar Techniques for Atmospheric Sensing, 5575, 16-30, 2004.

Wang, P. H., Minnis, P., McCormick, M. P., Kent, G. S., and Skeens, K. M.: A 6 year climatology of cloud occurrence frequency from stratospheric aerosol and gas experiment II observations (19851990), J. Geophys. Res., 101, 29407-29429, 1996.

Waugh, D. W.: Impact of potential vorticity intrusions on subtropical upper tropospheric humidity. J. Geophys. Res.,110, D11305, doi:10.1029/2004JD005664, 2005.

Waugh, D. W. and Polvani, L. M.: Climatology of intrusions into the tropical upper troposphere, Geophys. Res. Lett., 27, 3857-3860, 2000. 
Winker, D. M. and Trepte, C. R.: Laminar cirrus observed near the tropical tropopause by LITE, Geophys. Res. Lett., 25, 33513354, 1998.

Winker, D. M., Pelon, J., and McCormick, M. P.: The CALIPSO mission: spaceborne lidar for observation of aerosols and clouds, Proceedings of SPIE, 4893, 1-11, 2003.
Zhang, M. and Geller, M. A.: Selective excitation of tropical atmospheric waves in wave-CISK: The effect of vertical wind shear. J. Atmos. Sci., 51, 353-368, 1994. 